\title{
Social support for postpartum mothers with postpartum depression: scoping review
}

\author{
Ikha Muflikha ${ }^{1 *}$, Rosmita Nuzuliana ${ }^{2}$, Sri Lestari $^{3}$ \\ 1,2,3Universitas 'Aisyiyah Yogyakarta, Jalan Siliwangi, Yogyakarta and 55292, Indonesia \\ muflikha81@gmail.com ${ }^{1 *}$, Rosmitanz@unisayogya.ac.id² , tari.unisa@gmail.com³ \\ *corresponding author
}

Submission date: 24 Maret 2021, Receipt date: 2 April 2021, Publication date: 1 Juli 2021

\begin{abstract}
In Indonesia, the incidence of postpartum depression accounts for $50 \%$ to $70 \%$ of postpartum women. Therefore, ladies within the postnatal amount would like a social support from individuals around them to adapts to their new role as mothers. The purpose of this study was to determine the social support of research on postpartum mothers who experienced postpartum depression. Five stages were wont to conduct scoping a review. The 5 stages embrace characteristic analysis queries, characteristic relevant studies, choosing studies, charting knowledge, and an aggregation, summarizing and reportage the results. It was found 4 themes emerged as a result of the scoping review comprising of husband support, family support, friend support and self-efficacy for mothers experiencing postpartum depression. This study discusses that social support for postpartum mothers who experience postpartum depression is very necessary because the support of family, husband, friends and self can reduce the level of depression experienced by mothers. the support obtained is also different such as emotional support, instrumental support, and informational support. It could be conclude that the social support obtained from husband, family, friends, and self-efficacy is very important to reduce the rate of postpartum depression. The research gap was used as a reference in future research. It is hoped that researchers can develop research on the factors correlated to postpartum depression.
\end{abstract}

Keywords: postpartum, social support, postpartum depression

\section{INTRODUCTION}

In Taiwan, 39 women (21\%) scored quite high on the Edinburgh Postpartum Depression or EPDS scale. Participants showed that they have scores above 10 and more than 10 which was at 4 weeks postpartum (Lin Ho, et al., 2013). In 1960, in the United States, The prevalence of a postpartum depression was 3\% to $6 \%$. Then, in 1980, this case increased to $20 \%$ and in 1990, increased to $26 \%$ (Nurbaeti, 2012, in Ibrahim, 2012).

Factors causing postpartum depression include a history of previous depression, social support, marital relations, obstetric factors (cesarean section, delivery with tools). Based on these factors, social support is the main factor that triggers postpartum 
depression. Social support is a form of attention, appreciation and assistance felt by other people or groups that can function as a tool to make adjustments to stress, consisting of several forms, namely emotional support, appreciation support, instrumental support and information support. The influence of social support can affect a person's psychology.

Research conducted by Kristianto (2015) in Yogyakarta found that the prevalence of postpartum depression was $24.6 \%$, social support, income, parity had a significant relationship with the incidence of postpartum depression. Research by Corigan, et al (2015) stated that an the increase in a social support. scores is Associated with a lower incidence of a postnatal depression. It means that Mothers who have high social support scores greatly affect the level of depression. Therefore, The lack of a social support is a risk factor for a postpartum depression. In general, the social support can supports confidence and a trust in performing the role of a mother. The purpose of this study was to determine the social support of research on postpartum mothers who experienced postpartum depression

\section{RESEARCH METHOD}

This review used a methodology for clustering reviews. The stages administered in this scoping review consist of (1) identifying research questions, (2) identifying relevant studies, (3) selecting studies, (4) charting data, (5) compiling, summarizing, and reporting the results. This scoping review used 3 databases, which were Pub med, EBSCO, and Google Scholar (Arksey \& O'Malley., 2005). Then after the critical appraisal, 9 articles were obtained.

\section{Identification of the Scoping review question}

For this scoping review, the authors focused on the following research questions: How is the social support provided to postpartum mothers who experience postpartum depression?.

\section{Identification of relevant studies}

In searching for relevant studies, the authors used 3 databases including Pubmed, Google scholar, and EBSCO by using keywords that the authors had identified related to the scoping review topic in the search process. The words became the keywords in the search process included postpartum, postpartum depression, social support and added supporting keywords and other keywords which were the equivalent words of the main keyword to expand the search then organize and filter the years on the page such as abstract filtering, data publish 10 years, Human and English.

Table 1. Inclusion and Exclusion Criteria

\begin{tabular}{l|l}
\hline \multicolumn{1}{c|}{ Inclusion Criteria } & \multicolumn{1}{c}{ Exclusion Criteria } \\
\hline a. Articles from 2009 to 2019 & $\begin{array}{l}\text { a. Opinion articles } \\
\text { b. Articles in English or Indonesian }\end{array}$ \\
$\begin{array}{l}\text { b. Primary article } \\
\text { d. Documents / reports / draft policies / from WHO / specific book reviews } \\
\text { formal Organizations }\end{array}$ & $\begin{array}{l}\text { Review } \\
\end{array}$ \\
\hline
\end{tabular}

\section{Study Selection (Stage 3)}

The results of literature study were taken from 3 databases, namely Pubmed, Google Scholar, and Ebsco. Then a thorough title screening was carried out from the database 
using keywords. It was known that 146 articles were known by the author as having the ability to contribute information associated with the results the author needed to realize. Then 146 of these articles were screened again using confidence to facilitate article selection.

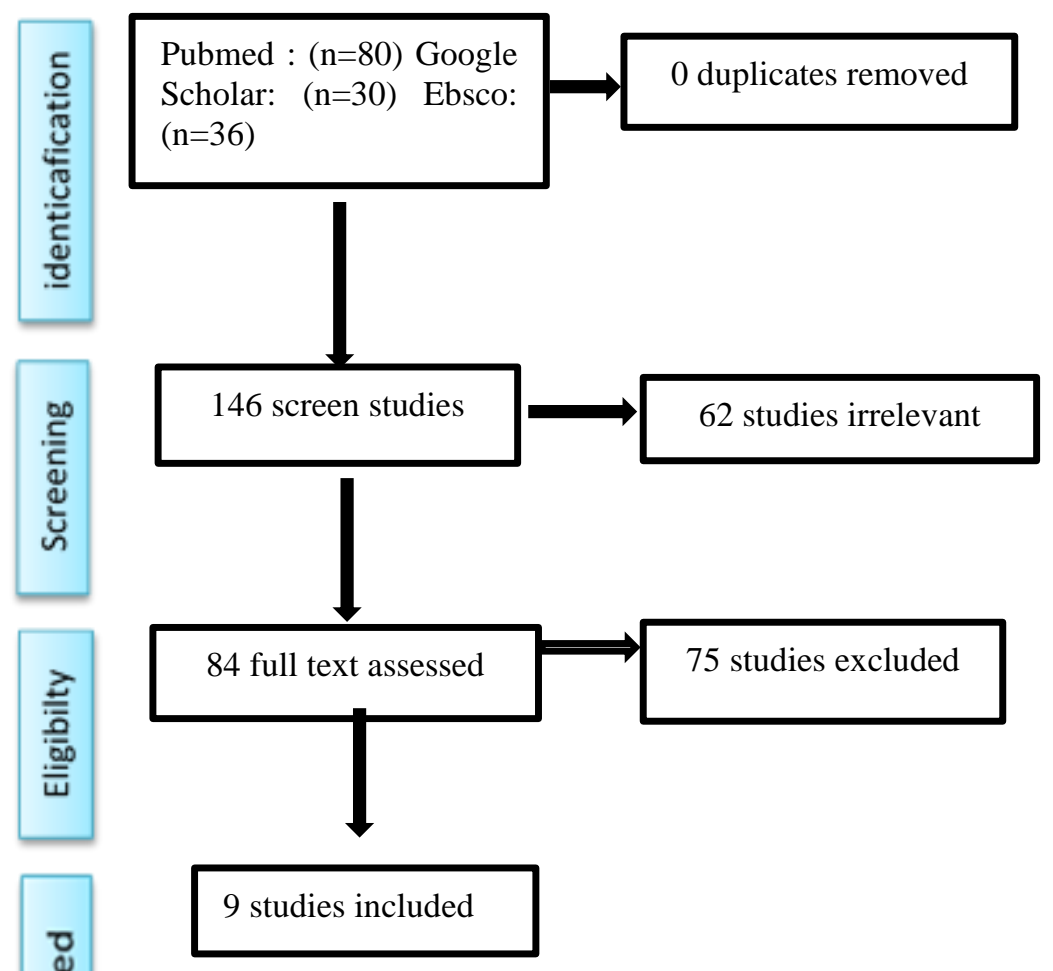

Figure 1. Prisma Flowchat

\section{Data Charting}

The 9 selected articles were then subjected to a critical appraisal process using the Joanna Briggs Institute Critical Appraisal Tools. JBI is an internationally based research and development organization, JBI focuses more on promotion and evidence-based health services by providing access to nurses, midwives, doctors, and other health workers. This institution collaborates internationally with more than 80 collaborating and serving 90 countries. In a scoping review, the quality of the study is not a criterion of primary concern, but rather an effort to find the breadth and depth of existing information, however, other studies revealed that an assessment of the quality of the articles in the scoping review was able to identify fundamental gaps in evidence. The next step is to collect and sort key information from selected articles such as Title / Author / Year / Grade, Country, Aim, Type of Research, Data Collection, Participants / Size and Results which are described in Table 2.

\section{Compile, Summarize, and Report the Results}

In this step, the writers tried to synthesize the data according to the research questions that had been previously set. Based on the 9 articles included, there were 4 syntheses in 
the form of grouped themes, namely husband support, family support, friend support, self-efficacy 
Table 2. Charting Data

\begin{tabular}{|c|c|c|c|c|c|c|c|}
\hline No. & $\begin{array}{c}\text { Title/ Author/ Year/ } \\
\text { Grade }\end{array}$ & Country & Aim & Type of Research & Data Collection & $\begin{array}{l}\text { Participants/ } \\
\text { sample size }\end{array}$ & Result \\
\hline 1. & $\begin{array}{l}\text { The social support, and a } \\
\text { postnatal depression in } \\
\text { low-a socioeconomic } \\
\text { level postnatal ladies in } \\
\text { eastern Turkey. }\end{array}$ & Turkey & $\begin{array}{l}\text { to determine risk factors for } \\
\text { postnatal depression in low- } \\
\text { level socioeconomic girls } \\
\text { throughout the primary } \\
\text { postnatal year and to see the } \\
\text { association between } \\
\text { symptoms postpartum } \\
\text { depression and social } \\
\text { support. }\end{array}$ & Quantitative & questionnaire & $\begin{array}{l}785 \text { samples of } \\
\text { mothers referred to } \\
\text { health centers } \\
\text { Malatya, an } \\
\text { Eastern Turkish } \\
\text { city, during the first } \\
\text { year after giving } \\
\text { birth. }\end{array}$ & $\begin{array}{l}\text { The results show that the lack of } \\
\text { emotional support from the } \\
\text { husband causes postpartum } \\
\text { depression And the prevalence } \\
\text { of postpartum depression } \\
\text { symptoms in. the mother is } 21 \% \text {. }\end{array}$ \\
\hline 2. & $\begin{array}{l}\text { Seeking a social support, } \\
\text { and a postpartum } \\
\text { depression: A pilot the } \\
\text { retrospective study of } \\
\text { perceived changes. }\end{array}$ & $\begin{array}{l}\text { New England } \\
\text { Or amerika } \\
\text { serikat }\end{array}$ & $\begin{array}{l}\text { An evaluation } \\
\text { interventions that specialize } \\
\text { in a social support in real- } \\
\text { world settings for ladies } \\
\text { with less PPD. During this } \\
\text { pilot study we to tend to ask } \\
\text { what proportion felt } \\
\text { changes over a time within } \\
\text { the } 3 \text { styles of a social } \\
\text { support (significant } \\
\text { different, a family, and } \\
\text { friends) in participants } \\
\text { United Nations agency } \\
\text { wanted to facilitate, and } \\
\text { attended the postnatal peer } \\
\text { support teams was related } \\
\text { to perceiving changes in a } \\
\text { depression over the amount. } \\
\text { An equivalent time. }\end{array}$ & Quantitative & Internet survey & $\begin{array}{l}\text { postpartum women } \\
\text { who participated in } \\
\text { the survey study }\end{array}$ & $\begin{array}{l}\text { The results show that } 57 \text { women } \\
\text { who get support from friends } \\
\text { greatly contribute to reducing } \\
\text { postpartum depression because } \\
\text { support from friends affects the } \\
\text { mother's experience of caring for } \\
\text { the baby. }\end{array}$ \\
\hline 3. & $\begin{array}{l}\text { Relationship between } \\
\text { Social Supportand } \\
\text { Postpartum Depression }\end{array}$ & $\begin{array}{l}\text { Abbottabad } \\
\text { and } \\
\text { Kabupaten } \\
\text { Mansehra }\end{array}$ & $\begin{array}{l}\text { To measure the prevalence } \\
\text { of PPD among married girls, } \\
\text { and additionally to look at } \\
\text { the connection of a social }\end{array}$ & Quantitative & $\begin{array}{l}\text { approachable from } \\
\text { the postnatal ward } \\
\text { and clinic of the } \\
\text { Hospital }\end{array}$ & $\begin{array}{lr}1000 \text { women } & \text { from } \\
\text { Hospital } & \text { and } \\
\text { Postnatal } & \text { Clinic } \\
\text { The } & \text { sample }\end{array}$ & $\begin{array}{l}\text { The results concluded that the } \\
\text { overall prevalence of postpartum } \\
\text { depression was women and the } \\
\text { study indicated that there was a }\end{array}$ \\
\hline
\end{tabular}

Copyright (@) 2021, International Journal of Health Science and Technology ISSN 2685-8673 (online) 


\begin{tabular}{|c|c|c|c|c|c|c|c|}
\hline & & & $\begin{array}{l}\text { support to the severity of a } \\
\text { postnatal depression.. }\end{array}$ & & & $\begin{array}{l}\text { consisted of } 200 \\
\text { mothers, aged 18- } \\
45 \text { years from } \\
\text { various educational } \\
\text { backgrounds and } \\
\text { socioeconomic } \\
\text { status. }\end{array}$ & $\begin{array}{l}\text { relationship between social } \\
\text { support and postpartum } \\
\text { depression. Lack of husband's } \\
\text { support can cause depressive } \\
\text { symptoms in mothers after } \\
\text { childbirth. }\end{array}$ \\
\hline 4. & $\begin{array}{l}\text { Barriers to Optimal } \\
\text { Social Support in } \\
\text { the Postpartum Period. }\end{array}$ & $\begin{array}{l}\text { Allegheny } \\
\text { County }\end{array}$ & $\begin{array}{l}\text { To test for specific barriers } \\
\text { to maternal realization of } \\
\text { social The support } \\
\text { throughout the primary, a } \\
\text { postnatal year } \\
\text {. }\end{array}$ & Qualitative & Focus discussion & $\begin{array}{l}\text { Thirty-one ladies } \\
\text { UN agency gave a } \\
\text { birth within the } \\
\text { year before the } \\
\text { study enrollment } \\
\text { was recruited by } \\
\text { posting on many } \\
\text { community sites. }\end{array}$ & $\begin{array}{l}\text { The cause of postpartum } \\
\text { depression in this study was the } \\
\text { lack of support From the } \\
\text { husband, namely the lack of an } \\
\text { affection because the husband } \\
\text { went to work. }\end{array}$ \\
\hline 5. & $\begin{array}{l}\text { Social Support During } \\
\text { the Postpartum Period: } \\
\text { Mothers' Views on } \\
\text { Needs, Expectations, } \\
\text { and Mobilization of } \\
\text { Support }\end{array}$ & $\begin{array}{l}\text { New } \quad \text { York } \\
\text { City. }\end{array}$ & $\begin{array}{l}\text { to explore views and } \\
\text { postpartum mother } \\
\text { experiences with social } \\
\text { support after giving birth. }\end{array}$ & Qualitative & $\begin{array}{ll}\text { Focus } & \text { group } \\
\text { discussions } & \end{array}$ & $\begin{array}{l}\text { depressed mother } \\
\text { postpartum and 6- } \\
12 \text { months after } \\
\text { delivery }\end{array}$ & $\begin{array}{l}\text { Research shows that the lack of } \\
\text { income from the husband causes } \\
\text { postpartum depression so that } \\
\text { the mother cannot buy milk. }\end{array}$ \\
\hline 6. & $\begin{array}{l}\text { The association between } \\
\text { social support and } \\
\text { postpartum depression } \\
\text { in women: A cross } \\
\text { sectional study }\end{array}$ & Iran & $\begin{array}{l}\text { To investigate the } \\
\text { prevalence of maternal } \\
\text { postpartum depression and } \\
\text { its relationship to social } \\
\text { support }\end{array}$ & Quantitative & $\begin{array}{l}\text { recruited } \\
\text { convenience } \\
\text { sampling. } \\
\text { questionnaire }\end{array}$ & $\begin{array}{l}\text { Two hundred post- } \\
\text { partum mothers } \\
\text { with infants under } \\
6 \text { months of age } \\
\text { attending the } \\
\text { pediatric or } \\
\text { gynecological } \\
\text { outpatient unit for } \\
\text { self or infant } \\
\text { health, from July } \\
2015 \text { to December } \\
2015\end{array}$ & $\begin{array}{l}\text { The research shows that the } \\
\text { prevalence of postpartum } \\
\text { depression in postpartum } \\
\text { mothers is } 43.5 \% \text {. The lower } \\
\text { score of social support networks } \\
\text { is that mothers are depressed } \\
\text { compared to mothers who are } \\
\text { not depressed. This study states } \\
\text { that mothers who are depressed } \\
\text { are due to the lack of knowledge } \\
\text { that mothers have in caring for } \\
\text { babies and self-care during the } \\
\text { postpartum period because the } \\
\text { majority of their education is } \\
\text { low. }\end{array}$ \\
\hline
\end{tabular}

Copyright $\odot$ 2021, International Journal of Health Science and Technology

$$
\text { ISSN } \underline{\text { 2685-8673 }} \text { (online) }
$$




\begin{tabular}{|c|c|c|c|c|c|c|c|}
\hline 7. & $\begin{array}{l}\text { The quality of a life and } \\
\text { a depression following } \\
\text { childbirth: an impact of a } \\
\text { social support. }\end{array}$ & Australia & $\begin{array}{l}\text { To evaluate the impact of a } \\
\text { social support on the } \\
\text { postnatal depression and } \\
\text { health-related a top quality } \\
\text { of the life. }\end{array}$ & Quantitative & survey & $\begin{array}{l}320 \text { women were } \\
\text { recruited after the } \\
\text { birth of the baby in } \\
\text { the hospital }\end{array}$ & $\begin{array}{l}\text { It indicates that women with low } \\
\text { social support are more likely to } \\
\text { experience depression than } \\
\text { women who receive support. } \\
\text { family support greatly affects } \\
\text { the reduction of depression and } \\
\text { mother's quality of life }\end{array}$ \\
\hline 8. & $\begin{array}{l}\text { the prenatal Social } \\
\text { Support, Postnatal } \\
\text { Social Support, and } \\
\text { Postpartum Depression. }\end{array}$ & China & $\begin{array}{l}\text { To assess the connection } \\
\text { between a gestation and an } \\
\text { accouchement a } \\
\text { social support with a } \\
\text { postnatal depression (PPD). }\end{array}$ & Quantitative & Cohort & $\begin{array}{ll}534 & \text { pregnant } \\
\text { women } & \end{array}$ & $\begin{array}{l}103 \text { mothers experienced } \\
\text { postpartum depression due to } \\
\text { low husband support during } \\
\text { pregnancy and childbirth. } \\
\text { Therefore, the level of } \\
\text { experiencing postpartum } \\
\text { depression is higher. For support } \\
\text { during pregnancy, there is less } \\
\text { postpartum depression than at } \\
\text { delivery. }\end{array}$ \\
\hline 9. & $\begin{array}{l}\text { The impact of social } \\
\text { support on postpartum } \\
\text { depression: } \\
\text { mediator role of self- } \\
\text { efficacy }\end{array}$ & China & $\begin{array}{l}\text { to investigate the impact of } \\
\text { perceived social support on } \\
\text { postpartum depression in } \\
\text { women, And especially } \\
\text { focus on confirming the } \\
\text { mediator role of a self- } \\
\text { efficacy. }\end{array}$ & Quantitative & instrument & $\begin{array}{l}427 \text { mothers gave } \\
\text { birth from two } \\
\text { public hospitals in } \\
\text { Beijing. }\end{array}$ & $\begin{array}{l}\text { It indicates that the top self- } \\
\text { efficacy may be could be the } \\
\text { issue for a postnatal depression. } \\
\text { The results show that social } \\
\text { support is very influential on } \\
\text { mothers who experience } \\
\text { postpartum depression, so that } \\
\text { the mother can increase her self- } \\
\text { efficacy. The explanation for the } \\
\text { results of this review is that } \\
\text { postnatal girls with a less social } \\
\text { support ought to increase their } \\
\text { self-assessments a lot of } \\
\text { to cut the back depression.. }\end{array}$ \\
\hline
\end{tabular}




\section{RESULTS AND DISCUSSION}

\section{Husband's Support}

\section{a. Emotional support}

Based on the results of research by (Yagmur \& Ulukoca, 2010) and (kazmi et al 2013)showed that the lack of emotional support from the husband causes postpartum depression and the prevalence felt by mothers on postpartum depression symptoms is $21 \%$ so that there is a relationship between social support and postpartum depression. Here mothers who are depressed should get support from their partners, family and friends such as empathy, care and attention because the support of their husbands and families is very important for the mother's recovery. So this study is in line with Sarafino's theory (2007) which states that emotional support includes empathy, concern and concern for individuals. Usually, this support is obtained from a partner or family, such as providing an understanding of the problems being faced or listening to their complaints. The existence of this support will provide a sense of comfort, certainty, a feeling of belonging and being loved to the individual.

Xie et al (2009) stated that as many as 103 (19.29\%) women experienced postpartum depression because social support from their husbands was low at prenatal and postnatal times, so the level of depression increased. For prenatal support of $28.20 \%$ and postnatal support of $44.10 \%$. This study is in line with (Asselmann et al 2016) which states that of 59 depressed postpartum mothers, 27 (45.76\%) respondents did not receive husband support. The results of multivariate analysis showed that there was a relationship between husband's support and the incidence of postpartum depression at the Rumbia Health Center and Putra Rumbia Health Center in 2013 ( $\mathrm{p}=$ 0.000). Postpartum mothers who do not receive support from their husbands have a 6.013 times chance of developing postpartum depression when compared to postpartum mothers whose husbands support them.

Lack of support from husbands is due to lack of affection as explained by (Barkin, et al, 2014) research (2014) which states that the cause of postpartum depression in this study is the lack of husband's support here, namely lack of affection because husbands go to work and are less responsible for raising children so mothers ask for help. from the surrounding environment such as families living together or communities in the same area.

\section{b. Instrumental Support}

Based on Negron's research (2012) states that the lack of income support from the husband causes postpartum depression because the husband does not give money to buy milk. The husband's last education is high school education so it is very influential on the income earned and does not have health insurance so that there is less access to health services because the husband's income is not enough let alone to buy milk. This study is in line with the research of Gao et al. (2009) stated that husbands or families with low income levels make mothers more susceptible to postpartum depression. According to Notoatmodjo (2010), income has an effect on work because someone who has a permanent job will generate sufficient income. 


\section{Family Support}

\section{a. Emotional Support}

According to Sarafino (2007) states that emotional support includes a sense of empathy, concern and concern for individuals. Usually, this support is obtained from a partner or family, such as providing an understanding of the problems being faced or listening to their complaints. The existence of this support will provide a sense of comfort, certainty, a feeling of belonging and being loved to the individual. So the family is very important to provide support to mothers who experience this situation, because the family knows everything. Moreover, parents who care for and care for the mother of the baby must always give love, attention and a sense of comfort to the mother.

\section{b. Information Support}

Negron, et al (2013) states that the need for support and hope from new mothers is important for the recovery of the mother after giving birth. Future postpartum depression prevention efforts should integrate a strong focus on social support. Families always provide information about baby care, postnatal care, and so on, so that mothers get adequate support from their families to reduce postpartum depression in mothers. However, if the mother does not get information support from family, friends and partners, she will experience postpartum depression more quickly. In contrast to the results of (Neill, Cycon, \& Friedman) research (2019), which states that social support from friends contributes to a decrease in women with postpartum depression. Because information from friends is captured by mothers more than family, friends are people who know everything when we are away from family.

\section{Friend Support}

\section{a. Information Support}

Based on the results of (Neill, Cycon, \& Friedman) research (2019) showing that in a trial using a retrospective Internet survey based on a study of 57 women who attended a postpartum peer support group and completed the survey, experienced changes in perceived social support from friends, the results showed that social support from friends contributed to decrease postpartum depression in women. (Webster et al., 2011) shows that women with low social support experience depression than women who are provided with adequate support. Social support obtained from family and friends thus has a positive effect on the quality of life.

\section{Self-Efficacy}

Based on the results of Vaezi, et al (2018), it shows that the prevalence of postpartum depression is $43.5 \%$ in new mothers. Social support network score is 2.09 0.99; were lower in depressed mothers compared with non-distressed mothers $(1.78$ 0.87 vs 2.331 .00 respectively, $\mathrm{P}<0.001)$. In this study, mothers who are depressed are due to the lack of knowledge that mothers have in caring for babies and postpartum self-care because the majority of their education is low. According to (Zhang \& Jin, 2014) research results show that high self-efficacy is a social protector for postpartum depression. The results show that the influence of social support on postpartum depression becomes involved in the self-efficacy section. The reason for this result is that postpartum women with lower social support should have lower self-assessment. 
Based on the results of research by Webster et al (2011) it shows that women with low social support experience depression than women who are given adequate support. Social support obtained from family and friends thus has a positive effect on quality of life because interventions to reduce depression and improve quality of life after childbirth should focus on friends and family, not just the mother. Ideally, the intervention would be initiated during pregnancy as would the quality of life between the groups.

\section{CONCLUSION}

Based on the above results, it can be concluded that social support obtained from husbands, family, friends, and self-efficacy is very important to reduce postpartum depression. The lower the social support, the higher the mother will experience postpartum depression, so the support needed must be appropriate and adequate during the postpartum period. Support can be given in the form of emotional, information, tangible help, and self-assessment.

\section{RECOMMENDATION}

It is expected that mothers can provide more information about postpartum depression, applying knowledge on the prevention of postpartum depression. Then the husbands can increase the attention and affection for the mother during the postpartum period in order to reduce postpartum depression and increase the mother's self-efficacy. For families, they can accompany and provide support regarding the needs of the postpartum period and baby care to the mother so that it can reduce the problem of postpartum depression. The findings of further research can develop research on factors associated with postpartum depression.

\section{THANK-YOU NOTE}

Thank you to Universitas 'Aisyiyah Yogyakarta that has helped me during making this scoping review.

\section{REFERENCES}

Asselmann, E., Wittchen, H., Erler, L., \& Martini, J. (2016). Peripartum changes in social support among women with and without anxiety and depressive disorders prior to pregnancy: a prospective-longitudinal study. https://doi.org/10.1007/s00737-016-0608-6

Barkin, J. L., Bloch, J. R., Hawkins, K. C., \& Thomas, T. S. (2014). Barriers to Optimal Social Support in. 445-454. https://doi.org/10.1111/1552-6909.12463

Ibrahim, F. (2012). Faktor-Faktor Yang Berhubungan Dengan Depresi Postpartum Di RSIA Pertiwi Makassar. Makassar : Biostatistik FKM Unhas.

kazmi S. Farhana, Munza, K., Tahir Roshan, Sher, D., \& Khan Asima Mehboob. (2013). Relationship between Social Support and Postpartum Depression. 9(4), 191-194.

Kristianto B. (2015). Hubungan Dukungan Sosial Dengan Depresi Pasca Persalinan di Puskesmas Mergangsan Kota Yogyakarta. Universitas Gadjah Mada. 
Negron, R., Martin, A., Almog, M., Balbierz, A., \& Howell, E. A. (2013). Social Support During the Postpartum Period: Mothers 'Views on Needs, Expectations, and Mobilization of Support. 616-623. https://doi.org/10.1007/s10995-012-1037-4

Vaezi, A., Soojoodi, F., Tehrani, A., \& Nojomi, M. (2018). The association between social support and postpartum depression in women : A cross sectional study. Women and Birth. https://doi.org/10.1016/j.wombi.2018.07.014

Webster, J., Nicholas, C., Velacott, C., Cridland, N., Nursing, M., Fawcett, L., ... Mental, C. (2011). Quality of life and depression following childbirth: impact of social support. Midwifery, 27(5), 745-749. https://doi.org/10.1016/j.midw.2010.05.014

Xie, R., Ms, C., He, G., Koszycki, D., Sych, C. P., Walker, M., \& Wen, S. H. I. W. U. (2009). Prenatal Social Support, Postnatal Social Support, and Postpartum Depression. (September 2007), 3-9. https://doi.org/10.1016/j.annepidem.2009.03.008

Zhang, Y., \& Jin, S. (2014). The impact of social support on postpartum depression: the mediator role of self-efficacy. https://doi.org/10.1177/1359105314536454 